\title{
Wild-type function of the p53 tumor suppressor protein is not required for apoptosis of mouse hepatoma cells
}

\author{
Christina Unger ${ }^{1}$, Albrecht Buchmann ${ }^{1}$, \\ Christoph L Buenemann ${ }^{1}$, Stefan Kress ${ }^{1}$ and \\ Michael Schwarz ${ }^{1,2}$ \\ 1 Institute of Toxicology, University of Tübingen, Wilhelmstr. 56, 72074 \\ Tübingen, Germany \\ 2 corresponding author: Michael Schwarz. tel: (0) 7071-29-77398; \\ fax: (0): 7071-29-2273; e-mail: michael.schwarz@uni-tuebingen.de
}

Received 8.7.97; accepted 7.8.97

Edited by G. Melino

\begin{abstract}
The role of the tumor suppressor protein p53 in apoptosis of mouse hepatoma cells was studied. Different lines were used which were either p53 wild-type or carried various types of heterozygous or homozygous p53 mutations. The presence of mutations was demonstrated to correlate with a lack in transactivating activity of p53. While UV-light effectively produced apoptosis in cells of all lines, irrespective of their p53 mutational status, $\gamma$-irradiation induced the formation of micronuclei but failed to induce apoptosis. Both UV- and $\gamma$ irradiation led to nuclear accumulation and increases in p53 protein in p53 wild-type cells. Similarly, no significant differences in apoptotic response between p53 wild-type and p53 mutated cells were seen with other apoptotic stimuli like CD95/APO-1/Fas or TNF $\alpha$. These data suggest that wildtype p53 is not required for induction of apoptosis in mouse hepatoma cells which may explain the apparent lack of p53 mutations in mouse liver tumors.
\end{abstract}

Keywords: apoptosis; p53; mouse hepatoma cells; CD95/ APO-1/Fas; tumor necrosis factor

Abbreviations: ActD, actinomycin D; Mab, monoclonal antibody; TNF, tumor necrosis factor $\alpha$

\section{Introduction}

The tumor suppressor p53 plays an important role in cellular responses to stress conditions. Exposure of cells to a variety of DNA damaging agents leads to a rise in p53 protein which is mediated by a post-transcriptional mechanism and is associated with the transcriptional activation of p53 responsive genes (for recent reviews see Haffner and Oren, 1995; Levine, 1997). As a consequence, cells may become arrested in the cell cycle to allow for DNA repair or undergo active cell death (apoptosis) under circumstances of severe impairment of cellular functions. The activation of these processes is also believed to be responsible for the tumor suppressor function of $p 53$. The wild-type function of $p 53$ is abrogated in about $50 \%$ of human cancers by point mutation or deletion of the gene (Greenblatt et al, 1994), while rodent tumors appear to harbor p53 mutations less frequently. In particular p53 mutations have not been detected so far in mouse liver tumors (for a summary see Schwarz et al, 1995). The reason for this discrepancy is unclear but it appears likely that there is a positive selection for p53 mutated hepatocytes in the human, but not the mouse liver. One of the driving forces relevant in the selection process may be apoptosis mediated by p53. In fact, p53-dependent apoptosis has been shown to suppress tumor growth and progression in vivo (Clarke et al, 1993; Graeber et al, 1996; Kemp et al, 1994; Symonds et al, 1994; Yin et al, 1997), and p53 protein is required for induction of apoptosis under several different physiological conditions. While normal mouse thymocytes will undergo apoptosis in

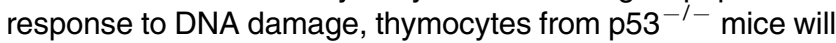
not (Lowe et al, 1993). Similarly, stem cells of the large and small intestine epithelia undergo apoptosis upon whole body irradiation of p53 wild-type mice, while such an effect is not observed in $\mathrm{p5}^{-1-}$ mice (Kitada et al, 1996; Merritt et al, 1994). Elimination of functional p53 may therefore be associated with a decrease in the rate of apoptosis which could lead to a clonal outgrowth of the p53-deficient cells. In this paper we report that apoptosis induced by various stimuli in mouse hepatoma cells does not depend on wild-type p53 function which may explain why there is no selection for p53mutated cells in mouse liver. Hepatoma cells with mutated p53, however, were positively selected when co-cultured with p53 wild-type cells, suggesting that p53 mutations confer a selective growth advantage to mouse hepatoma cells in vitro but not in vivo.

\section{Results}

In the present study we have used cells of various mouse hepatoma lines, which have been previously established and characterized regarding their p53 mutational status (Kress et al, 1992). Some characteristic features of the various cell lines are summarized in Figure 1. Cells of lines 55.1c, 53.2d, and $56.1 \mathrm{c}$ do not harbor detectable p53 mutations (w/w). In line $56.1 \mathrm{~d}$, one p53 allele is point-mutated and the other deleted $(\mathrm{m} / \mathrm{d})$; in line 70.4 both p53 alleles are altered by point mutations $(\mathrm{m} / \mathrm{m})$, and line $56.1 \mathrm{~b}$ is heterozygous with regard to $p 53(\mathrm{~m} / \mathrm{w})$. The basal levels of p53 protein in the various lines were studied by immunoprecipitation and Western analysis using monoclonal antibodies Mab421 and Mab246 which detect the mutated and the wild-type conformation (Mab421), or only the wild-type conformation of the protein (Mab246). No or very weak p53-specific signals were detectable in various wild-type lines including line $55.1 \mathrm{c}$ with either antibody (Figure 1). The expected signal was obtained with Mab421 in the three lines carrying a mutated p53 allele, demonstrating that cells of these lines express elevated basal 


\begin{tabular}{|c|c|c|c|c|c|}
\hline cell line & $55.1 c^{*}$ & $56.1 d$ & 70.4 & $56.1 b$ & \\
\hline p53 status & $w / w$ & $\mathrm{~m} / \mathrm{d}$ & $\mathrm{m} / \mathrm{m}$ & $\mathrm{m} / \mathrm{w}$ & \\
\hline $\begin{array}{c}\text { mutation } \\
\text { (codon) }\end{array}$ & no & 132 & $\begin{array}{l}135 \\
138\end{array}$ & 277 & \\
\hline base subst. & no & $C: G / G: C$ & $\begin{array}{l}G: C / C: G \\
C: G / G: C\end{array}$ & $\mathrm{G}: \mathrm{C} / \mathrm{C}: \mathrm{G}$ & \\
\hline AA change & no & $C->W$ & $\begin{array}{l}A->P \\
C->W\end{array}$ & $\mathrm{R}->\mathrm{T}$ & \\
\hline $\begin{array}{c}\text { p53 } \\
\text { expression }\end{array}$ & $-\infty$ & 0 & - & --- & p53 \\
\hline antibody & 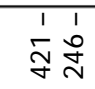 & \begin{tabular}{ll} 
& 1 \\
\cline { 1 - 1 } & $\stackrel{\circ}{\sim}$
\end{tabular} & 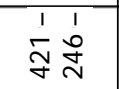 & 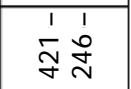 & \\
\hline $\begin{array}{l}\text { p53 } \\
\text { relative } \\
\text { reporter } \\
\text { activity }\end{array}$ & 86.3 & 0.4 & 1.0 & 6.6 & \\
\hline
\end{tabular}

Figure 1 p53 status of mouse hepatoma lines. The various cell lines were established from carcinogen-induced mouse liver tumors and have been characterized with respect to the presence of p53 mutations in a previous study (Kress et al, 1992). The top panels represent a summary of the results: w: p53 wild-type; m: p53 mutated; $d$ : deletion of one p53 allele. The expression of p53 protein was determined by immunoprecipitation using p53 monoclonal antibodies which either detect both the wild-type and the mutated conformation (Mab421) or only the wild-type conformation (Mab246) of the protein. The transactivating activity of p53 was analyzed by use of a p53 luciferase reporter transfected into cells of the various cell lines. Values were normalized for protein concentration and Renilla luciferase activity (internal standard). The p53-specific activity is expressed as fold increase over values obtained by transfection of the basic luciferase control vector. Values represent means of 6 transfections. S.D. of the absolute activities did not exceed $15 \%$ of the means. ${ }^{*}$ In addition to cell line $55.1 \mathrm{c}$, two other p53 wildtype lines, $53.2 \mathrm{~d}$ and $56.1 \mathrm{c}$, were used in the present study. Expression and transactivating activity of p53 was only determined in $55.1 \mathrm{c}$ cells

levels of p53 protein. Mab246 yielded clearcut signals in line $56.1 \mathrm{~b}(\mathrm{~m} / \mathrm{w})$ and very weak signals in lines $56.1 \mathrm{~d}(\mathrm{~m} / \mathrm{d})$ and $70.4(\mathrm{~m} / \mathrm{m})$. The transactivating activity of p53 was subsequently studied in cells of lines $55.1 \mathrm{c}, 70.4,56.1 \mathrm{~d}$ and $56.1 \mathrm{~b}$ by transfection of cells with a p53 luciferase reporter construct (Butz et al; 1995, Funk et al, 1992). In comparison to values obtained with the basic luciferase control vector, an 86-fold increase in reporter activity was observed in cells of the p53 wild-type line 55.1c (Figure 1), while this value was decreased to 6.6 -fold in cells of the p53 heterozygous line $56.1 \mathrm{~b}(\mathrm{~m} / \mathrm{w})$. No increases in relative reporter activity were seen with cells of lines $70.4(\mathrm{~m} / \mathrm{m})$ and $56.1 \mathrm{~d}(\mathrm{~m} / \mathrm{d})$. We subsequently investigated the role of endogenous p53 during apoptosis, which was induced in cells of the various lines by different stimuli. The presence of DNA-ladders derived from cytosolic DNA separated on agarose gels was used as a reliable semiquantitative marker. Figure 2 shows the results obtained with UV- and $\gamma$-irradiation of cells. Twenty-four hours after a single dose of $70 \mathrm{~J} / \mathrm{m}^{2}$ of UV-light, typical DNA-laddering was observed in cells of all five lines investigated, irrespective of their p53 mutational status. Cells of lines $56.1 \mathrm{~b}(\mathrm{w} / \mathrm{m})$ and $56.1 \mathrm{~d}(\mathrm{~m} / \mathrm{d})$ appeared to be most sensitive in this assay. The dose dependency of UV-irradiation was studied in lines 55.1c $(\mathrm{w} / \mathrm{w})$ and $70.4(\mathrm{~m} / \mathrm{m})$, demonstrating that apoptosis was already induced at a dose of $10 \mathrm{~J} / \mathrm{m}^{2}$ in cells of both lines, of which line $55.1 \mathrm{c}$ was slightly more sensitive than line 70.4 (Figure 2B). In contrast to UV-light, $\gamma$-irradiation (8.4 Gy) of cells of all five hapatoma lines investigated failed to induce apoptosis when analyzed $24 \mathrm{~h}$ after irradiation (Figure 2). To confirm these results, we scored for the presence of apoptotic nuclei in bisbenzimide (Hoechst 33258)- stained cells. At $24 \mathrm{~h}$ after irradiation with UV-light, apoptotic cells showing typical nuclear abnormalities such as condensed chromatin and nuclear fragmentation were observed at high frequency in all lines (exemplified for cells of lines 55.1c and 70.4 in Figure $3)$. The apoptotic cells were almost exclusively found detached from the Petri dish in the medium while in the population of adherent cells apoptotic figures were very rarely detectable. In agreement with the biochemical data on DNAladdering, $\gamma$-irradiation did not increase the frequency of apoptotic nuclei in cells of any of the lines investigated. The genotoxic effects of $\gamma$-irradiation, however, were clearly visible by the presence of micronuclei in cells adhering to the Petri dishes (Figure 3; see also 46). We have previously shown that $\gamma$-irradiation of cells of the p53 wild-type line $55.1 \mathrm{c}$ leads to a rapid and transient nuclear accumulation of p53 protein, an effect that is not observed with cells of line 70.4 harboring mutated p53 alleles (Unger et al, 1994). Similarly, UV-light led to nuclear accumulation of p53 in cells of line $55.1 \mathrm{c}$ as demonstrated in Figure 4A, showing the p53 immunostaining patterns of control and UV-irradiated cells. UV-mediated increases in p53 protein could also be demonstrated by Western analysis, and the effects on p53-protein were even more dramatic in cells of line 55.1c $\gamma$-irradiated with 8.4 Gy (Figure 4B). In summary, apoptosis was induced by UV-light both in p53 wild-type and mutated cells while $\gamma$-irradiation failed to do so, even though it induced increases in p53 (this paper) and nuclear accumulation of the protein (Unger et al, 1994) in p53 wild-type cells.

The effect of CD95-Mab was investigated next. Interestingly, CD95-Mab failed to induce apoptosis when incubated alone with cells of the five mouse hepatoma lines studied (Figure 5A). This result was somewhat unexpected since this agonist of the CD95 death receptor is highly effective at inducing apoptosis in primary mouse hepatocytes (Ni et al, 1994). Since reverse transcriptase PCR demonstrated the expression of CD95 mRNA in all lines (Figure 5B), lack of response to the antibody is probably not due to a lack of expression of the death receptor. Apoptosis was very effectively induced in cells of all lines, irrespective of their p53 mutational status, by combinational treatment with ActD and CD95-Mab. This effect appeared to be mostly, if not entirely, mediated by the transcriptional inhibitor, since incubation of cells with ActD alone induced DNA-laddering similar to that seen upon combinational treatment. Only in cells of line $55.1 \mathrm{c}$, we reproducibly observed overadditive effects upon combinational treatment (Figure 5A). In addition to CD95-Mab, we also tested TNF as apoptosis-inducing agent in the two selected cell lines $55.1 \mathrm{c}(\mathrm{w} / \mathrm{w})$ and $70.4(\mathrm{~m} / \mathrm{m})$. The results were almost identical to the ones obtained with CD95-Mab: ActD alone effectively induced apoptosis while TNF alone was 
$\mathbf{A}$

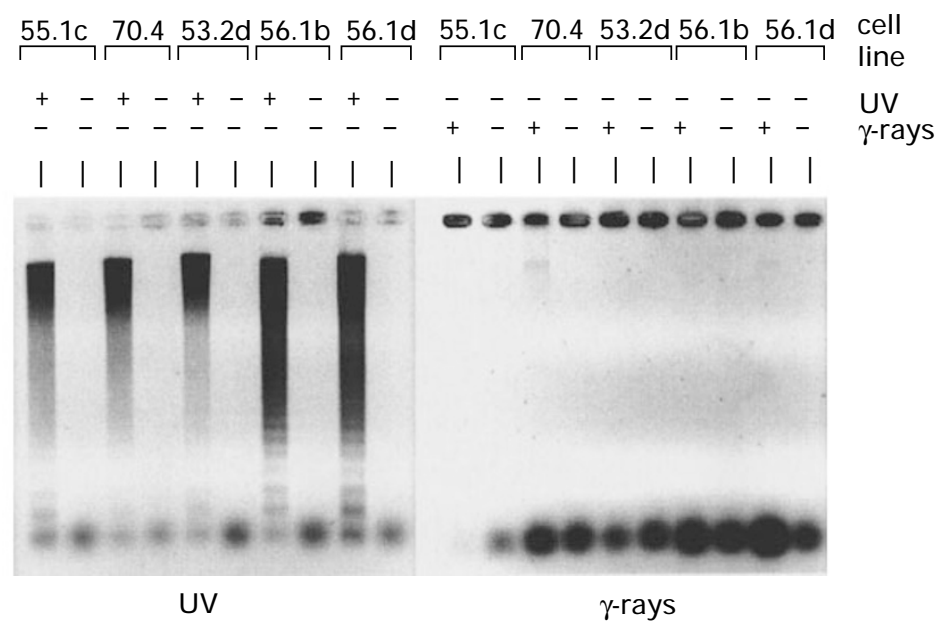

B

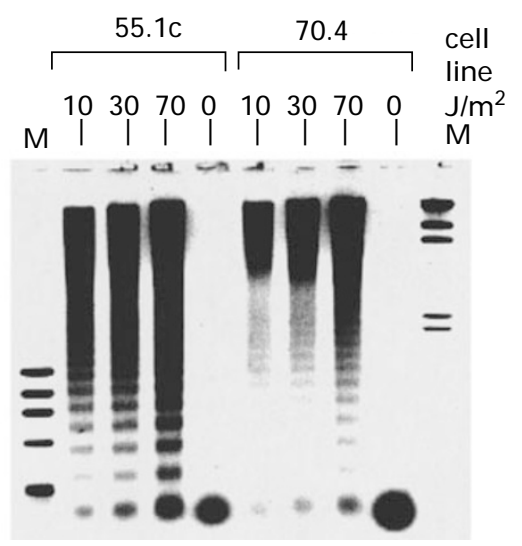

Figure 2 DNA-laddering in mouse hepatoma cells exposed to UV- and $\gamma$-irradiation. For induction of apoptosis, cells of the indicated lines were UV-irradiated with $70 \mathrm{~J} / \mathrm{m}^{2}$ or $\gamma$-irradiated with $8.4 \mathrm{~Gy}(\mathbf{A})$ or various doses of UV-light. (B) Twenty-four hours post-irradiation, cells adhering to the Petri dish and detached cells were harvested and combined. Cytoplasmic DNA was isolated and separated by agarose gel electrophoresis. M: marker DNA. The gels were stained with ethidium bromide and the UV fluorescence was registered by use of a CSC video camera. The results shown are representative for at least two independent experiments. For the sake of clearness of presentation the pictures in the figures show the inverted signals

UV
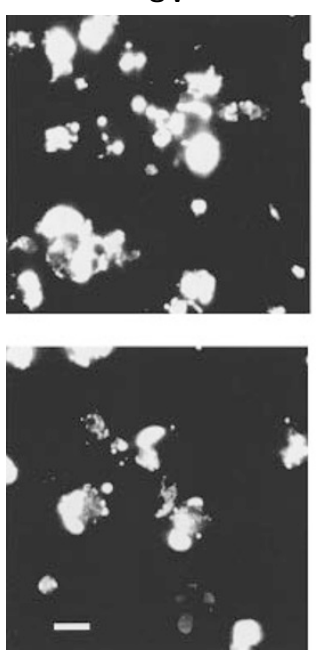

$\gamma$-rays
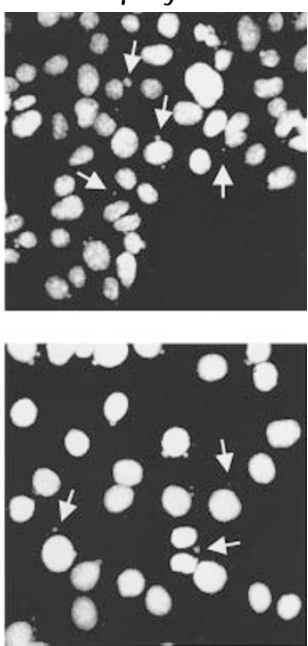

A
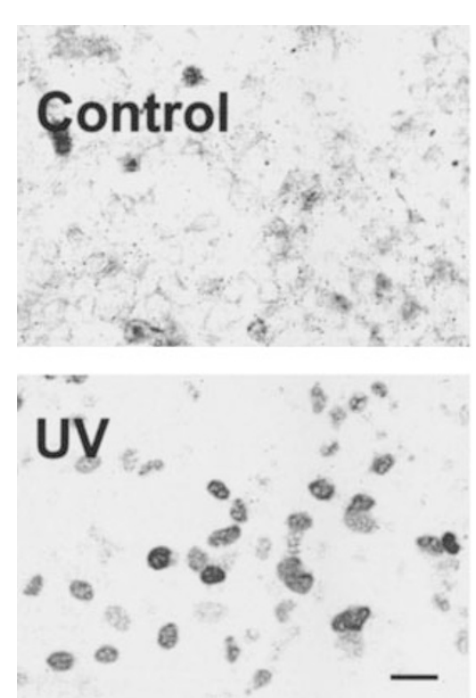

Figure 4 Induction of p53 protein by UV- and $\gamma$-irradiation in p53 wild-type cells of line 55.1c. (A) Immunohistochemical demonstration of nuclear accumulation of p53 protein in cells exposed to $70 \mathrm{~J} / \mathrm{m}^{2}$ of UV and analyzed $20 \mathrm{~h}$ later. Bar, $25 \mu \mathrm{m}$. (B) Increases in p53 protein by UV- and $\gamma$-irradiation as demonstrated by immunoprecipitation and Western analysis. Cells were irradiated with the indicated doses and analyzed $20 \mathrm{~h}$ (UV) and $2 \mathrm{~h}(\gamma$-rays) later

and mutated (70.4) cells. Members of the Bcl-2 family are associated with apoptosis and some of them have been demonstrated to be regulated by $\mathrm{p} 53$ protein. We have studied the expression of $\mathrm{Bax}, \mathrm{Bcl}-2$, and $\mathrm{BCl}-\mathrm{x}_{\mathrm{L}}$ by Western analysis. The basal levels of Bax differed slightly between the various lines (Figure 6); there was, however, no obvious correlation with the p53 mutational status of the cells and the concordant transcriptional activity of p53 (see
B

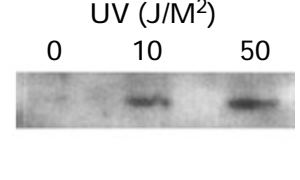

$\gamma$-rays (Gy)

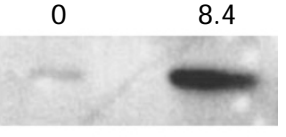

cells of both lines into apoptosis. There were no significant differences in this response between p53 wild-type (55.1c) ineffective. Only in cells of line 55.1c, which were somewhat more sensitive compared to cells of line 70.4 TNF plus ActD was more effective than ActD alone (Figure $5 \mathrm{C})$. The effects of serum withdrawal on apoptosis in cells of lines 55.1c and 70.4 were subsequently investigated. Incubation for 24 or $48 \mathrm{~h}$ in serum-free medium triggered

Figure 3 Demonstration of apoptotic nuclei and micronuclei in mouse $70 \mathrm{~J} / \mathrm{m}^{2} \mathrm{UV}$-light or were $\gamma$-irradiated with $8.4 \mathrm{~Gy}$. Twenty-four hours later, cell cells of both lines detached from the Petri dishes showed characteristic 
Figure 1). Bcl-2 was not detectable in any of the mouse hepatoma lines analyzed (not shown). Bcl- $\mathrm{x}_{\mathrm{L}}$ levels were found to be similar in all five hepatoma lines investigated (Figure 6). UV-irradiation and serum withdrawal, but not ActD/CD95-Mab treatment, led to slight increases in Baxexpression in cells of lines 55.1c and 70.4, apparently regardless of their p53 mutational status (Figure 7 ). Bcl- $x_{L}$ levels were almost unaffected by UV-irradiation and serum withdrawal but were significantly reduced in cells of both lines treated with ActD/CD95-Mab (Figure 7). This latter effect is most likely due to inhibition of transcription by ActD. The fact that $\mathrm{Bcl}-\mathrm{x}_{\mathrm{L}}$ was much stronger decreased in line $55.1 \mathrm{c}$ when compared to line 70.4 is in accordance with the higher sensitivity of the former cells towards CD95/ ActD-mediated apoptosis. Decrease in $\mathrm{Bcl}-\mathrm{x}_{\mathrm{L}}$, however, is clearly not a general requirement for apoptosis of mouse hepatoma cells. The quantitative evaluation of the Western blots allowed the determination of the $\mathrm{Bax} / \mathrm{Bcl}-\mathrm{x}_{\mathrm{L}}$ ratio, which was generally increased (1.2-4.2-fold) in cells triggered into apoptosis (calculated from data in Figure 7).

We have previously shown that the mutations and deletions in p53 in the lines used in the present study occurred during in vitro propagation of the hepatoma cells, suggesting that the mutations in the tumor suppressor gene conferred a selective advantage to the mutated cells (Kress et al, 1992). To test this hypothesis, mixing experiments were performed, where cells carrying p53 mutations were co-cultivated with their p53 wild-type counterparts and the fate of both populations was followed during sequential passaging. For this purpose
A

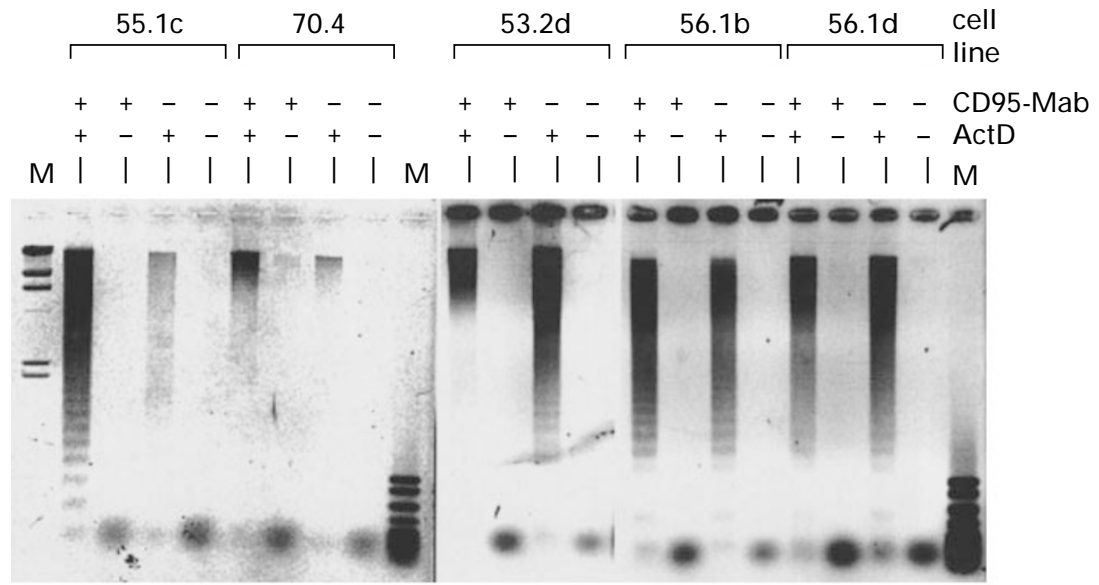

B

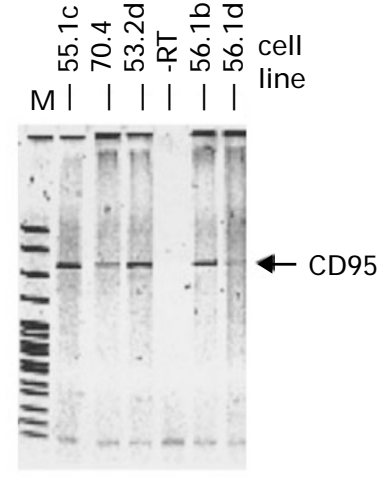

C

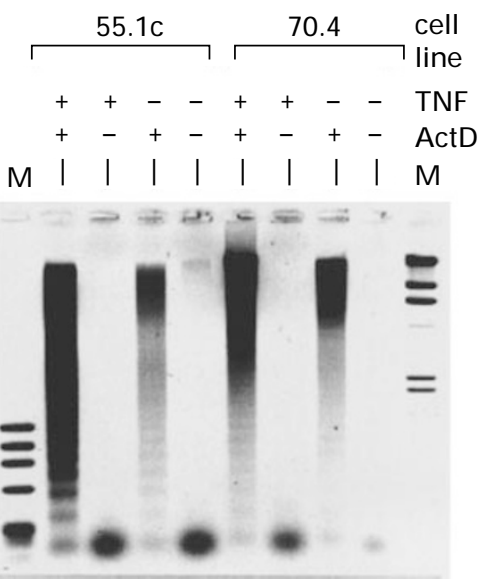

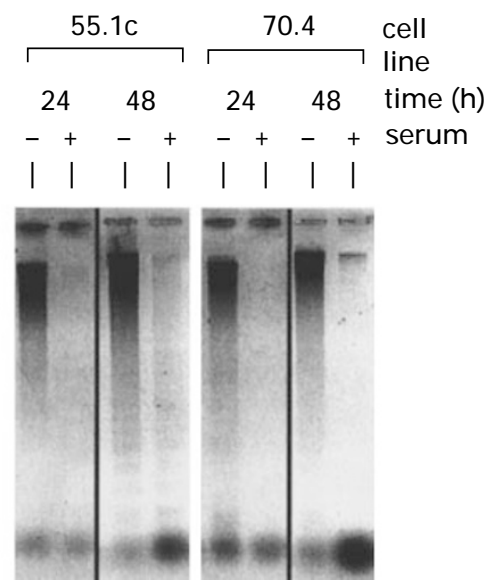

Figure 5 Induction of DNA-laddering in mouse hepatoma cells by different stimuli. Following $24 \mathrm{~h}$ of incubation with the various agents, laddering of cytoplasmic DNA was demonstrated by agarose gel electrophoresis and ethidium bromide staining. (A) Cells of the indicated hepatoma lines were treated with CD95-Mab (1 $\mu$ g/ $\mathrm{ml})$, ActD $(50 \mathrm{ng} / \mathrm{ml})$, or a combination of both. (B) Demonstration of CD95 receptor by RT - PCR in cells of the indicated lines. RNA from untreated control cells was isolated and reverse transcribed. cDNA was PCR amplified, separated by polyacrylamide gel electrophoresis and ethidium bromide stained (lane-RT: omission of reverse transcriptase in the reaction with RNA from cells of lane 53.2d). (C) DNA-laddering in cells of lines $55.1 \mathrm{c}$ and 70.4 treated with TNF (100 ng/ml), ActD $(50 \mathrm{ng} / \mathrm{ml})$ or both. (D) DNA-laddering after serum withdrawal for 24 or $48 \mathrm{~h}$. M: marker DNA. UV fluorescence of the ethidium bromide-stained gels were recorded by use of a CSC-video camera. The results shown are representative for at least two independent experiments. The pictures show the inverted signals 
we used cells of lines $56.1 \mathrm{c}(\mathrm{w} / \mathrm{w})$, lines $56.1 \mathrm{~b}(\mathrm{~m} / \mathrm{w})$ and $56.1 \mathrm{~d}(\mathrm{~m} / \mathrm{d})$ which are isogenic because they were all derived from one and the same primary mouse tumor. These cells cannot be easily discriminated on the basis of morphological criteria, but p53 PCR products yielded distinctly different banding patterns upon single strand conformational (SSCP) analysis (Kress et al, 1992) which allowed us to distinguish between cells of the different populations by molecular analysis of their genotype. Wildtype and mutated cells were mixed at an initial ratio of $100: 1$ and the cells were subsequently propagated for up to six passages. With increase in passage number, signals specific for the mutated cells of lines $56.1 \mathrm{~b}$ (Figure $8 \mathrm{~A}$ ) and 56.1d (Figure 8B) increased in intensity, demonstrating that the ratio of p53 wild-type and p53 mutated cells changed during this period. In the case of cells from line $56.1 \mathrm{~d}$, which lack wild-type p53, we were able to demonstrate that six passages of co-cultivation were sufficient to extinguish p53 wild-type cells in the final population. The analysis of the generation times of cells of the three lines yielded mean doubling times of $15.6 \mathrm{~h}$ for line $56.1 \mathrm{c}(\mathrm{w} / \mathrm{w}), 13.5 \mathrm{~h}$ for line $56.1 \mathrm{~b}(\mathrm{~m} / \mathrm{w})$ and $12.7 \mathrm{~h}$ for

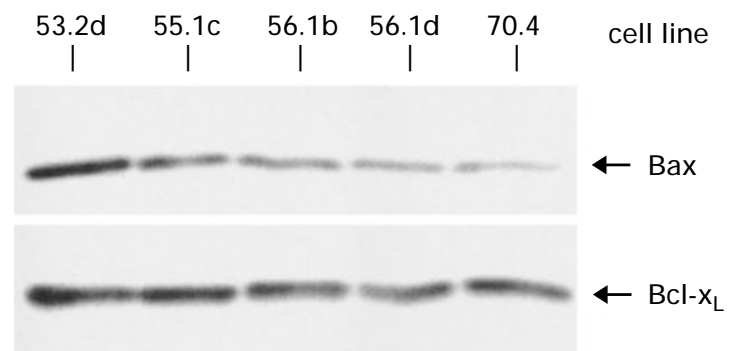

Figure 6 Basal levels of Bax and Bcl- $x_{L}$ in mouse hepatoma cells. Cellular extracts were separated by SDS-PAGE and proteins were detected by Western blotting and CDP-star chemiluminescence reaction using a CSCcamera for visualization of signals line $56.1 \mathrm{~d}(\mathrm{~m} / \mathrm{d})$, respectively. These results suggest that mutations in the p53 gene affect the cell cycle kinetics and negatively select against mouse hepatoma cells with the functional tumor suppressor protein.

\section{Discussion}

The tumor suppressor gene p53 is inactivated by mutation or deletion in about $50 \%$ of all human tumors, implying that loss of its wild-type function represents a very important step during the development of these cancers (Greenblatt et al, 1994). In contrast to human primary hepatocellular

A

B
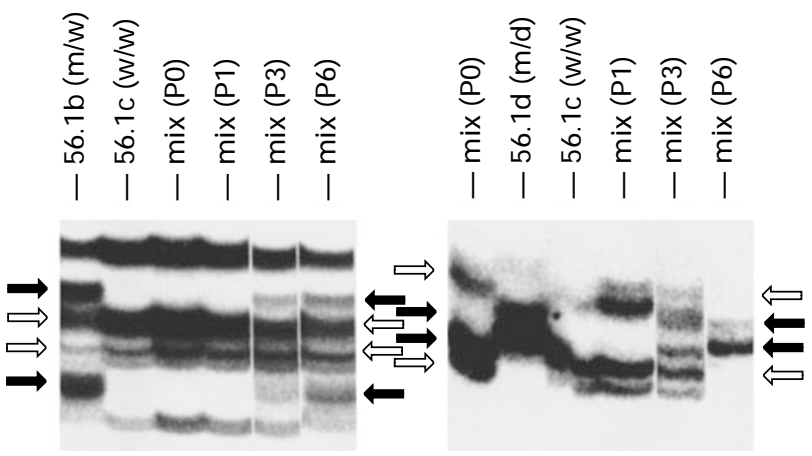

Figure 8 Negative selection of p53 wild-type cells during co-cultivation with isogenic p53 mutated cells. Cells of the p53 wild-type line $56.1 \mathrm{c}(\mathrm{w} / \mathrm{w})$ were mixed at an initial ratio of 100:1 (P0) with cells of either line $56.1 \mathrm{~b}(\mathrm{~m} / \mathrm{w} ; \mathbf{A})$ or $56.1 \mathrm{~d}(\mathrm{~m} / \mathrm{d}$; B) and were subsequently co-cultivated for up to six passages (P1-P6). Fragments (from exon 8 in A and exon 5 in B), including the p53 mutations, were PCR amplified and examined by SSCP analysis. Samples from the pure cell lines are also included. Note the partial disappearance of DNA bands from p53 wild-type (55.1c) cells (open arrows) and the appearance of bands representing DNA from the p53 mutated cells (filled arrows) during in vitro propagation of cells

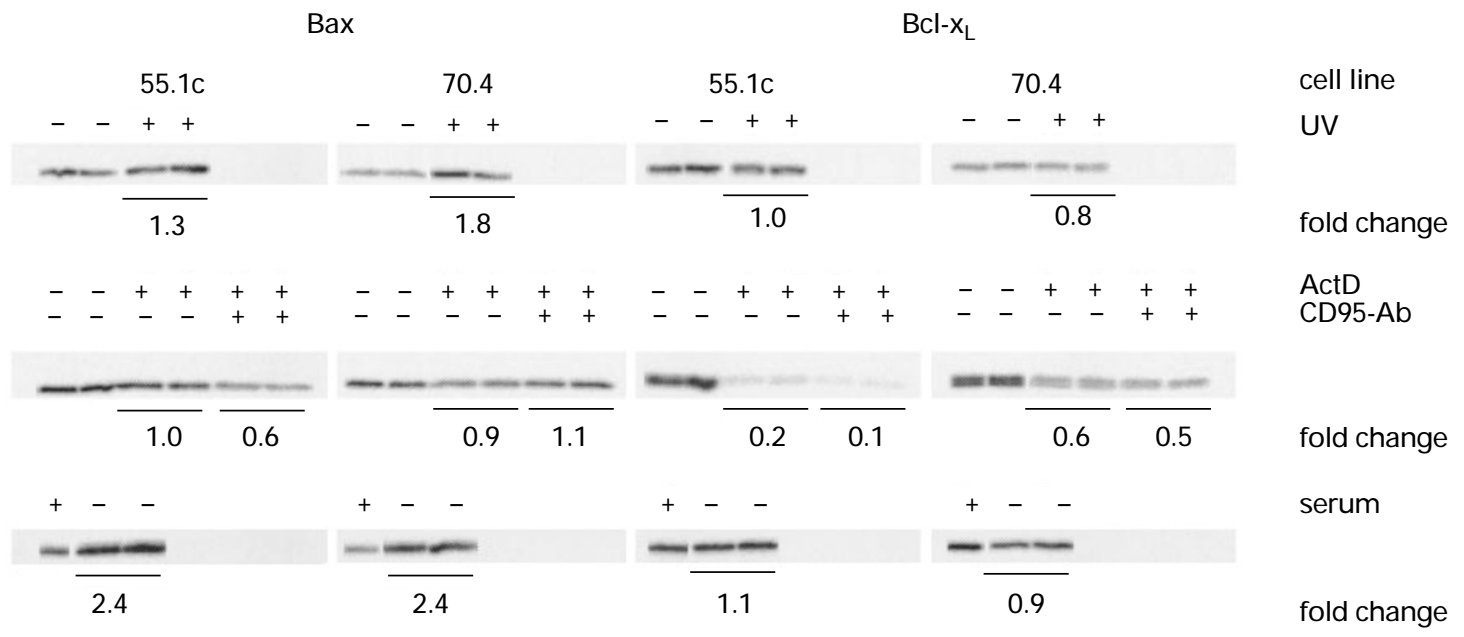

Figure 7 Changes in the expression of Bax and Bcl- $x_{L}$ in mouse hepatoma cells treated with various apoptotic stimuli. Cells of lines $55.1 \mathrm{c}$ and 70.4 were exposed to UV-light $\left(70 \mathrm{~J} / \mathrm{m}^{2}\right)$, ActD $(50 \mathrm{ng} / \mathrm{ml})$ and/or CD95-Mab $(1 \mu \mathrm{g} / \mathrm{ml})$ or were serum-starved for $48 \mathrm{~h}$. Bax and Bcl- $\mathrm{X}_{\mathrm{L}}$ proteins were detected by Western blotting and chemiluminescence reaction using a CSC-camera for visualization of signals. Signal intensities were quantified by image analysis and expressed as fold change relative to values obtained with untreated control cells 
carcinomas, liver tumors from mice appear to lack p53 mutations (for a survey see Schwarz et al, 1995). The most likely explanation for this remarkable difference in biological behavior is that there exists a selective advantage in the human liver tumors for those cells that carry a mutation in the p53 gene, while this selective pressure is not present in the mouse liver tumors (Kemp, 1995). One of the key factors that govern tumor growth is apoptosis which may be mediated by p53, and the available evidence suggests that elimination of wild-type p53 function by mutation or deletion of the gene strongly affects tumor growth because the mutated tumor cells may become resistant to apoptosis triggered by the tumor suppressor protein (Graeber et al, 1996, Symonds et al, 1994, Yin et al, 1997). The results of the present study suggest that such a selection mechanism for p53-mutated cells is not operative during mouse hepatocarcinogenesis since wild-type p53 function is not required for induction of apoptosis in mouse hepatoma cells. This assumption is based on several lines of evidence:

First; there were no significant differences in apoptotic response to four different apoptotic stimuli between p53 wildtype and p53 mutated cells. In the case of CD95-Maband TNF-induced apoptosis this may be explained by the fact that these agents elicit their effect via specific transmembrane receptors and signal via death domain containing proteins (for a review see Nagata, 1997), presumably without requirement of p53, althoughinversely-p53-mediated induction of the CD95/ligand system has been described (Mueller et al, 1997; OwenSchaub et al, 1995). In the case of DNA-damaging treatments, however, such as UV- or $\gamma$-irradiation, one might have expected an involvement of p53, based on results obtained in other cell systems. For example, wildtype p53 is required for radiation-induced apoptosis in mouse thymocytes (Clarke et al, 1993; Lowe et al, 1993; Midgley et al, 1995), cells at the stem cell position of mouse small intestine and colon epithelia (Kitada et al, 1996; Merritt et al, 1994) or mouse skin (Kemp et al, 1993). Moreover, p53-deficient mice are highly susceptible to radiation-induced tumorigenesis, which is at least partly due to a defect in p53-mediated apoptosis (Kemp et al, 1994). Mechanisms independent of p53 may also exist, since lymphocytes from $\mathrm{p} 53^{-1-}$ mice activated to proliferate undergo apoptosis upon $\gamma$-irradiation (Strasser et al, 1994).

Second; in cells of the wild-type line 55.1c, both UV-light and $\gamma$-irradiation led to nuclear accumulation of p53 (see Figure 4 and Figure 1 in ref. Unger et al, 1994, respectively) and increased cellular levels of p53 protein, as demonstrated by Western analysis. In this respect, $\gamma$ irradiation was even more effective than UV-light, while only the latter treatment induced apoptosis in mouse hepatoma cells. The observation that $\gamma$-irradiation does not induce apoptosis in mouse hepatoma cells is in line with results obtained upon in vivo whole body irradiation of mice (MacCallum et al, 1996), which demonstrated that $\gamma$ irradiation does not induce apoptosis of hepatocytes and cells of other radioresistant organs such as brain, skeletal muscle, kidney and lung. One remarkable difference between in vivo and in vitro, however, lies in the irradiation-mediated accumulation of p53 protein in the p53 wild-type hepatoma cells, which is not observed in hepatocytes in vivo (MacCallum et al, 1996).

All mutations present in the mouse hepatoma cells used in this study reside in the sequence-specific DNA binding domain of p53 (Levine, 1997). Mutations within the DNA binding domain impair the function of p53 to act as transcription factor, an effect that could be clearly reproduced in this study by use of a p53-reporter assay. There are conflicting results in the literature with respect to the requirement of sequence-specific DNA binding and transcriptional activity of p53 for induction of apoptosis. For example, wild-type p53 expressed in certain human and rat cells was capable of inducing apoptosis, while transcriptionally inactive mutants failed to do so (Friedlander et al, 1996; Sabbatini et al, 1995). However, induction of apoptosis by p53 through mechanisms that appear transcriptionallyindependent have been observed in other experimental systems (Caelles et al, 1994; Chen et al, 1996; Haupt et al, 1995; Rowan et al, 1996). Finally, synergisms between transcription-dependent and independent functions of p53 in induction of apoptosis have been suggested (Chen et al, 1996). In summary, the available experimental evidence suggests that both, transcriptional activities of p53 and activities independent of transcription can play a role in p53mediated apoptosis and that the reasons for obtaining conflicting results may be due to differences in the cell types and experimental conditions used.

Members of the bcl-2 gene family, some of which may be transcriptionally regulated by $\mathrm{p} 53$, play an important role in the regulation of apoptosis. While proteins like $\mathrm{Bcl}-2$ and $\mathrm{Bcl}-\mathrm{x}_{\mathrm{L}}$ inhibit apoptosis, others like Bax promote apoptosis (Boise et al, 1993; Oltvai et al, 1993). Since different members of the Bcl-2 family can form homo- and heterodimers which differentially affect apoptosis, the relative ratios of pro- and anti-apoptotic $\mathrm{Bcl}-2$ family proteins appear to determine the resistance or sensitivity of cells to diverse apoptotic stimuli (Oltvai and Korsmeyer 1994; Sedlak et al, 1995). The bax promoter contains p53 consensus sequences and p53 protein is a positive regulator of Bax expression (Merchant et al, 1996; Miyashita et al, 1994; Miyashita and Reed, 1995). Apoptosis-associated $\mathrm{Bax}$ and $\mathrm{Bcl}-\mathrm{x}_{\mathrm{L}}$ induction by ionizing radiation was found to be dependent on functional p53 (Zhan et al, 1994, 1996), however, Bax-mediated enhancement of apoptosis may also occur independent of p53 (Strobel et al, 1996). With respect to hepatoma cells, differing results on the expression of Bcl-2 family proteins during apoptotis have been reported. While no alterations in the levels of $\mathrm{Bax}$ and $\mathrm{Bcl}-2$ were observed in human HepG2 hepatoma cells triggered into apoptosis by different apoptotic stimuli including UV-light (Jiang et al, 1996), induction of Bax was seen in human Hep3B hepatoma cells treated with spingosin-1-phosphate (Hung and Chuang 1996). Since Hep3B cells are p53-deficient, this increase in Bax expression is not mediated by p53 protein (Hung and Chuang 1996). We also found increases in Bax protein levels in UV-exposed and serum-deprived cells of both p53 wild-type (55.1c) and double-mutated (70.4) hepatoma 
lines, suggesting that transcriptional activation by $p 53$ is not required for Bax expression in these cells.

Our observation that wild-type p53 function is not required for apoptosis of mouse hepatoma cells gives a plausible explanation for the absence of p53 mutations in mouse liver tumors since loss of functional p53 would not provide a selection advantage. During in vitro propagation of hepatoma cells, however, p53 mutations confer a growth advantage to the mutated cell populations (Kress et al, 1992). This was confirmed in the present study by the results obtained by co-cultivation of isogenic hepatoma cells with different p53 status (wild-type or mutant). In contrast to a similar experiment with rat1 cells which were kept under hypoxic conditions as a strong selective treatment (Graeber et al, 1996), the driving force in our experiments with mouse hepatoma cells is probably not p53-mediated apoptosis. Selection for p53 mutated hepatoma cells could also be due to an activation of cell cycle checkpoints by wild-type p53 (for a review see Levine, 1997). We hypothesize that trypsination and detachment from the substrate, routinely required for propagation of cells in vitro, generate stress conditions that lead, in p53 wild-type cells, to a partial block at the $\mathrm{G}_{1} /$ $S$ or $G_{2} / M$ borders of the cell cycle, thus negatively selecting against these cells in the presence of cells that lack functional p53. Since hepatocytes in vivo do not experience this type of selection pressure, p53 mutated hepatoma cells will clonally expand in vitro but not in vivo.

\section{Materials and Methods}

\section{Cell lines and induction of apoptosis}

The cell lines used in the present study carrying different p53 mutations were established from mouse liver tumors and have been characterized earlier in detail (Kress et al, 1992). Cells were grown in modified Dulbecco's Eagle's medium in a humidified incubator containing $5 \% \mathrm{CO}_{2}$ at $37^{\circ} \mathrm{C}$ as described (Kress et al, 1992). Cells were routinely passaged twice a week by trypsination $(0.05 \%$ trypsin plus $0.02 \%$ EDTA in $\mathrm{Ca}^{2+}$ and $\mathrm{Mg}^{2+}$ free phosphate buffered saline). For induction of apoptosis $2-4 \times 10^{5}$ cells (depending on the proliferation kinetics of cells from the different lines) were seeded into $10 \mathrm{~cm}$ culture dishes. After 2 days of cultivation, apoptosis was induced in subconfluent cultures by different stimuli.

UV-light Cells were irradiated at doses between 10 and $70 \mathrm{~J} / \mathrm{m}^{2}$ using a Stratalinker (Stratagene).

$\gamma$-irradiation Cells were irradiated with 8.4 Gy using a Linac SL 15 (Philips) linear accelerator.

CD95 antibody (CD95-Mab) and tumor necrosis factor $\alpha$ (TNF) Cells were incubated with $1 \mu \mathrm{g} / \mathrm{ml}$ CD95-Mab (Pharmingen) dissolved in PBS or $100 \mathrm{ng} / \mathrm{ml}$ of murine TNF (gift of Dr. A Wendel, Konstanz, Germany) dissolved in $0.9 \% \mathrm{NaCl}$ containing $0.2 \%$ human serum albumin for varying lengths of time. In parallel incubations, $50 \mathrm{ng} / \mathrm{ml}$ of actinomycin $\mathrm{D}$ (ActD, dissolved in $70 \%$ ethanol) were added to the assays along with CD95-Mab or TNF, or cells were incubated with ActD alone.

Serum starvation Cells were washed with PBS and incubated in serum free medium for $24-48 \mathrm{~h}$.

\section{Transfections and transient expression assays}

Cells were inoculated in 24-well plates at a density of 75000 to 100000 cells per well. After $24 \mathrm{~h}$, cells were incubated for transfection with cationic liposomes (Maxifectin $\mathrm{M}$ ) and plasmid DNA using a kit kindly provided by Dr. A Surovoy (Institute of Organic Chemistry, University of Tuebingen, Germany). The reporter plasmids used were p53CON containing a single $19 \mathrm{bp}$ p53-recognition sequence upstream of a minimal heat shock protein 70 promoter linked to the firefly luciferase gene and the basic vector pGUP.PA.8, which is identical to p53CON, except that it is devoid of the p53 binding site (Funk et al, 1992; kindly provided by Dr. JW Shay, University of Texas, Dallas). Cells were transfected with $400 \mathrm{ng}$ per well of either of the two reporter plasmids together with $5 \mathrm{ng}$ of $\mathrm{pRL}-\mathrm{CMV}$, containing the CMV immediate-early enhancer/promoter region linked to the Renilla luciferase gene (Promega), the latter one being used for normalization. Twenty-four hours after transfection, cells were lysed directly on the plate, aliquots were withdrawn for measuring protein concentrations, and enzyme activities were determined using the dual-luciferase reporter assay system (Promega). Quantification was performed on a Lumat LB 9507 luminometer (Berthold). Results represents six separate transfections, the values varying by less than $15 \%$.

\section{Determination of apoptosis}

For demonstration of DNA laddering which is characteristic for apoptotic cells, cytoplasmic DNA was isolated according to Hockenberry et al (1990) as modified by Lindenboim et al (1995). For this purpose, the supernatants of the cell incubations containing medium and non-adherent cells were collected; adherent cells were washed with PBS, which was also collected. Remaining cells were trypsinized and resuspended in fresh medium. All three suspensions were then combined, cells were pelleted by centrifugation ( $200 \mathrm{~g}, 5 \mathrm{~min}$, room temperature) and resuspended in 5-10 ml PBS. At this step, $500 \mu \mathrm{l}$ aliquots were used for determination of total cellular DNA following Hoechst 33258 staining (Labarca and Paigen, 1980). Cells were then washed once with PBS, pelleted and lysed in $1 \mathrm{ml}$ of a buffer $(0.5 \%$ Triton $\mathrm{X}-100,5 \mathrm{mM}$ Tris, $20 \mathrm{mM}$ EDTA, pH 7.4) for $20 \mathrm{~min}$ on ice. The lysate was centrifuged for $15 \mathrm{~min}$ at $13800 \mathrm{~g}\left(4^{\circ} \mathrm{C}\right)$ and the supernatant containing the cytoplasmic DNA was collected. For DNA extraction, $500 \mu \mathrm{l}$ of phenol (equilibrated with TE buffer, $\mathrm{pH}$ 7.4) and $500 \mu \mathrm{l}$ of chloroform/isoamylalcohol (24/1) were added to $500 \mu \mathrm{l}$ of the supernatants, mixed for $5 \mathrm{~min}$ and centrifuged for $10 \mathrm{~min}$ at $13200 \mathrm{~g}$ at $4^{\circ} \mathrm{C}$. The phenolic phase was removed and the aqueous phase was reextracted with $500 \mu \mathrm{l}$ chloroform/ isoamylalcohol $(24 / 1)$, followed by a chloroform extraction. The DNA was then precipitated overnight at $-70^{\circ} \mathrm{C}$ by addition of 2 volumes of ethanol and 0.1 volume $3 \mathrm{M}$ sodium acetate, $\mathrm{pH} 5.2$, pelleted by centrifugation at $13200 \mathrm{~g}\left(10 \mathrm{~min}, 4^{\circ} \mathrm{C}\right)$, washed with $70 \%$ ethanol, and finally dissolved in $20 \mu \mathrm{l}$ TE buffer. RNA was digested by addition of DNAse-free RNAse A (final concentration $250 \mu \mathrm{g} / \mathrm{ml}$ ) and incubation for $30 \mathrm{~min}$ at $37^{\circ} \mathrm{C}$. Remaining protein traces were subsequently eliminated by incubation with proteinase $\mathrm{K}$ (final concentration $200 \mu \mathrm{g} / \mathrm{ml}$ ) for $1 \mathrm{~h}$ at $37^{\circ} \mathrm{C}$. Cytoplasmic DNAs were adjusted to equal amounts based on data obtained by quantitation of total cellular DNA and separated on a $1.2 \%$ agarose gel at $70 \mathrm{~V}$ for $3 \mathrm{~h}$. The gel was stained with ethidium bromide and the UV fluorescence was registered by use of a CSC video camera (Raytest).

For microscopic demonstration of apoptotic nuclei, adherent cells were washed with PBS, briefly fixed in acetone:methanol $1: 1$, washed 
with PBS and stained with bisbenzimide (Hoechst 33258; $10 \mu \mathrm{g} / \mathrm{ml}$ in PBS) for $15 \mathrm{~min}$. Non-adherent cells were collected from the supernatants by centrifugation at $200 \mathrm{~g}$, washed in PBS and incubated in a solution containing bisbenzimide $(40 \mu \mathrm{g} / \mathrm{ml}$ in PBS) for $15 \mathrm{~min}$. Aliquots of the cell suspension were dropped onto slides, covered with cover slips and directly evaluated under the fluorescence microscope.

\section{Demonstration of CD95 mRNA by RT - PCR}

Total cellular RNA was isolated with the RNeasy ${ }^{(-k i t}$ (Qiagen). Reverse transcription was performed for $45 \mathrm{~min}$ at $37^{\circ} \mathrm{C}$ using the $3^{\prime}$ primer 5'-CCAAGACACAGCAGAACAGA-3'. A 446 bp fragment was subsequently amplified following addition of Taq-polymerase (Stehelin) and the 5'-primer 5'-GACCCAGAATACCAAGTGCA-3' by 34 cycles of denaturing $\left(95^{\circ} \mathrm{C}\right)$, annealing $\left(55^{\circ} \mathrm{C}\right)$ and primer extension $\left(72^{\circ} \mathrm{C}\right), 1 \mathrm{~min}$ each. The primer sequences were derived from Tanaka et al (1994). Control assays were run without RNA and reverse transcriptase. The PCR products were separated on a $10 \%$ polyacrylamide gel and stained with ethidium bromide.

\section{Immunohistochemical demonstration of p53}

For immunohistochemistry, cells were placed onto 10-well multitest slides (ICN Biomedicals Inc.) at an initial density of $1-2 \times 10^{4}$ cells/ well. Overnight cultures were UV-irradiated at $70 \mathrm{~J} / \mathrm{m}^{2}$ and subsequently cultivated for $20 \mathrm{~h}$ before fixation with acetone:methanol $(1: 1)$ for $2 \mathrm{~min}$ at $4^{\circ} \mathrm{C}$. Fixed cells were incubated with normal goat serum ( $1: 20$ diluted in PBS) for $20 \mathrm{~min}$ and subsequently exposed for $1 \mathrm{~h}$ at room temperature to either anti-p53 Mab421 or Mab246 (Oncogene Science Inc), diluted 1:100 prior to use. After removal of the first antibody by repeated washes with PBS, cells were incubated for $1 \mathrm{~h}$ with a biotinylated anti-mouse secondary antibody (Biospa; $1: 200$ in PBS containing $1 \%$ albumin and $0.35 \mathrm{M} \mathrm{NaCl}$ ) followed by $30 \mathrm{~min}$ of incubation at room temperature with a streptavidin/alkaline phosphatase complex (Biospa) diluted 1:200 in PBS and staining with Fast Red (Kementec).

\section{Immunoprecipitation and Western analysis}

For p53 protein analysis, $10^{6}-10^{7}$ cells were lysed in the Petri dishes by addition of $1 \mathrm{ml}$ of lysis buffer ( $150 \mathrm{mM}$ Tris/ $\mathrm{HCl}, 5 \mathrm{mM}$ EDTA, $1 \%$ NP-40, $50 \mu \mathrm{M}$ leupeptine, $50 \mu \mathrm{g} / \mathrm{ml}$ aprotinin, $1 \mathrm{mM}$ PMFS, pH 8) and incubation for $30 \mathrm{~min}$ at $4^{\circ} \mathrm{C}$. After centrifugation of the lysate $(20 \mathrm{~min}$ at $11000 \mathrm{~g}, 4^{\circ} \mathrm{C}$ ), the protein content of the cytosol in the supernatant was determined by means of the Biorad protein assay (Biorad) and adjusted to equal protein contents. Subsequently, $1 \mathrm{ml}$ of lysate was preincubated for $1 \mathrm{~h}$ at $4^{\circ} \mathrm{C}$ with $100 \mu$ protein-G-agarose solution (Boehringer). Protein- $G$ beads were then precipitated at $10000 \mathrm{~g}$ $\left(5 \mathrm{~min}, 4^{\circ} \mathrm{C}\right.$ ) and equivalent amounts of the supernatants were incubated overnight with anti-p53 monoclonal antibodies 246 or 421 $(1 \mu \mathrm{l} \mathrm{Mab} / 100 \mu \mathrm{l}$ lysate). Thereafter $10 \mu \mathrm{l}$ protein-G-agarose solution per $100 \mu$ lysate were added and incubated for $1 \mathrm{~h}$ at $4^{\circ} \mathrm{C}$. The beads were pelleted, washed $3 \times$ with lysis buffer, resuspended in $20 \mu \mathrm{l}$ of loading buffer $(100 \mathrm{mM}$ Tris $/ \mathrm{HCl}, 200 \mathrm{mM}$ dithiothreitol, 4\% S.D.S., $20 \%$ glycerol, $0.2 \%$ bromophenol blue, $\mathrm{pH} 6.8$ ), and heated to $95^{\circ} \mathrm{C}$ for $10 \mathrm{~min}$. Proteins were then separated on a $10 \%$ S.D.S. polyacrylamide gel. After protein transfer to a PVDF membrane, the membrane was probed with rabbit anti-p53 Ab 565 (1: 10000, Chemicon Int.) and p53 protein was finally detected by enhanced chemiluminescence $(E C L$, Amersham).
For Bax and $\mathrm{Bcl}-\mathrm{x}_{\mathrm{L}}$ analysis, cells adhering to the Petri dish were washed twice with PBS and lysed in a lysis buffer $(50 \mathrm{mM}$ Tris/ $/ \mathrm{HCl}$, $150 \mathrm{mM} \mathrm{NaCl}, 0.1 \%$ (w./v.) S.D.S., $0.5 \%$ (w/v) sodium deoxycholate, $1 \%(\mathrm{v} / \mathrm{v})$ Triton $\mathrm{X}-100,10 \mathrm{mM}$ sodium pyrophosphate, $25 \mathrm{mM}$ sodium glycerophosphate, $2 \mathrm{mM}$ sodium orthovanadate, $2 \mathrm{mM}$ EDTA, $0.3 \mu \mathrm{M}$ aprotinin, $10 \mu \mathrm{M}$ leupeptine, $1 \mu \mathrm{M}$ pepstatin, $1 \mathrm{mM}$ PMSF, $\mathrm{pH}$ 7.2) on ice. Non-adhering cells were pelleted by centrifugation $(5 \mathrm{~min}, 170 \mathrm{~g}$, $4^{\circ} \mathrm{C}$ ), washed in a buffer consisting of $10 \mathrm{mM} \mathrm{Na}_{2} \mathrm{SO}_{3}, 1 \mathrm{mM}$ EDTA, $10 \mu \mathrm{M}$ pepstatin and $1 \mathrm{mM}$ PMSF and pelleted by centrifugation. Material from adhering and non-adhering cells was combined, sonicated (45 s) and centrifuged $\left(10000 \mathrm{~g}, 4^{\circ} \mathrm{C}\right)$. The protein content in the supernatants was determined according to Smith et al (1985), adjusted to equal concentrations and diluted with 1 Vol. $2 \times$ Lämmli, 1970). Proteins were subsequently separated by SDS - PAGE (15\% for Bax and 13.5\% for Bcl-x, $200 \mathrm{~V}, 60 \mathrm{~min}$ ) and transferred to PVDF membranes (Biorad). These were incubated with Bax (N-20, Santa Cruz) and Bcl-x (B22630, Transduction Laboratories) rabbit polyclonal antibodies for $45 \mathrm{~min}$ and $2 \mathrm{~h}$, respectively. After removal of the primary antibody, membranes were incubated with alkaline phosphatase-coupled goat anti rabbit IgG (Tropix) secondary antibody and CDP-star substrate (Tropix) and chemiluminescence signals were monitored by use of a CSC camera.

\section{SSCP analysis}

Sequences from mouse p53 exons 5 and 8 were amplified directly from cells by using the primer pairs MA1/MA14 and MB2/MB12, respectively, as previously described (Kress et al, 1992). Aliquots ( $2 \mu \mathrm{l}, 1 / 10$ diluted) of the p53 amplification reactions were reamplified for 15 rounds in a 'hot-mix' $(20 \mu \mathrm{l})$ containing unlabeled $(0.45 \mu \mathrm{M}$ each) and $5^{\prime}{ }^{32} \mathrm{P}$-labeled primers $(0.5 \mu \mathrm{M}$ each). SSCP analysis of p53 PCR products was carried out essentially as described (Kress et al, 1992). To $1.5 \mu \mathrm{l}$ of the second PCR reaction mixture $9 \mu \mathrm{l}$ of stop solution (95\% formamide, $20 \mathrm{mM}$ EDTA, $0.05 \%$ bromphenol blue and $0.05 \%$ xylene cyanol) were added, heated to $95^{\circ} \mathrm{C}$ for $3 \mathrm{~min}$, and chilled on ice. DNA fragments were separated by electrophoresis in a non-denaturing $6 \%$ polyacrylamide gel $(40 \times 20 \times 0.02 \mathrm{~cm})$ containing $5 \%$ glycerol at $30 \mathrm{~W}$ for $2.5-3 \mathrm{~h}$ under cooling with a fan. The gel was dried and exposed to Kodak XAR X-ray film overnight at room temperature.

\section{Computer generated images}

Fluorescence and chemiluminescence signals were recorded by use of a CSC video camera system (Raytest) and stored as TIFF files which were subsequently imported for presentation into COREL DRAW 5.0. Quantitative evaluation of chemiluminescence data was performed by use of the software program TINA 2.0 (Raytest). For the sake of clearness of presentation, the pictures in Figures 2-5 show the inverted CSC video signals.

\section{Acknowledgements}

We thank Dr. P Rodemann, Mrs. Löffler and Mrs. Turan for help in $\gamma$ irradiation of cells and A Schmiechen for advice in p53 reporter assay. Dr. JW Shay and Dr. F Hoppe-Seyler are acknowledged for gift of p53reporter plasmids. Dr. A Wendel is acknowledged for gift of murine TNF and Dr. A Surovoy is acknowledged for gift of maxifectin M. This work was supported by grant Bo306/14-4 of the Deutsche Forschungsgemeinschaft. 


\section{References}

Boise LH, Gonzales-Garcia M, Postema CE, Ding L, Lindsten T, Turka LA, Mao X, Nunez $\mathrm{G}$ and Thompson CB (1993) Bcl-x, a bcl-2-related gene that functions as a dominant regulator of apoptotic cell death. Cell 74: 597-608

Butz K, Shahabeddin L, Geisen C, Spitkovsky D, Ullmann A and Hoppe-Seyler F (1995) Functional p53 protein in human papillomavirus-positive cancer cells. Oncogene 10: $927-936$

Caelles C, Helmberg A and Karin M (1994) p53-dependent apoptosis in the absence of transcriptional activation of p53-target genes. Nature 370: 220-223

Chen X, Ko LJ, Jayaraman L and Prives C (1996) p53 levels, functional domains, and DNA damage determine the extent of the apoptotic response of tumor cells. Genes. Dev. 10: 2438-2451

Clarke AR, Purdie CA, Harrison DJ, Morris RG, Bird CC, Hooper ML and Wyllie AH (1993) Thymocyte apoptosis induced by p53-dependent and independent pathways. Nature $362: 849-852$

Friedlander P, Haupt Y, Prives C and Oren M (1996) A mutant p53 that discriminates between p53-responsive genes cannot induce apoptosis. Mol. Cell. Biol. 16 $4961-4971$

Funk WD, Pak DT, Karas RH, Wright WE and Shay JW (1992) A transcriptionally active DNA-binding site for human p53 protein complexes. Mol. Cell. Biol. 12: $2866-2871$

Graeber TG, Osmanian C, Jacks T, Housman DE, Koch CJ, Lowe SW and Giaccia AJ (1996) Hypoxia-mediated selection of cells with diminished apoptotic potential in solid tumours. Nature 37: 88-91

Greenblatt MS, Bennett WP, Hollstein M and Harris CC (1994) Mutations in the p53 tumor suppressor gene: clues to cancer etiology and molecular pathology. Cancer Res. 54: 4855-4878

Haffner R and Oren M (1995) Biochemical properties and biological effects of p53. Curr. Opin. Genet. Dev. 5: 84-90

Haupt Y, Rowan S, Shaulian E, Vousden KH and Oren M (1995) Induction of apoptosis in HeLa cells by transactivation-deficient p53. Genes Dev. 9: 21702183

Hockenbery D, Nuñez G, Milliman C, Schreiber RD and Korsmeyer S (1990) Bcl-2 is an inner mitochondrial membrane protein that blocks programmed cell death. Nature 348: $334-336$

Hung WC and Chuang LY (1996) Induction of apoptosis by sphingosine-1-phosphate in human hepatoma cells is associated with enhanced expression of bax gene product. Biochem. Biophys. Res. Commun. 229: 11-15

Jiang MC, Yang-Yen HF, Lin JK and Yen JJY (1996) Differential regulation of p53, $\mathrm{c}-\mathrm{Myc}, \mathrm{Bcl}-2$ and Bax protein expression during apoptosis induced by widely divergent stimuli in human hepatoblastoma cells. Oncogne 13: 609-616

Kemp CJ, Donehower LA, Bradley A and Balmain A (1993) Reduction of p53 gene dosage does not increase initiation or promotion but enhances malignant progression of chemically induced skin tumors. Cell 74: 813-822

Kemp CJ, Wheldon T and Balmain A (1994) p53-deficient mice are extremely susceptible to radiation- induced tumorigenesis. Nature Genetics 8: 66-69

Kemp CJ (1995) Hepatocarcinogenesis in p53-deficient mice. Mol. Carcinogenesis 12: $132-136$

Kitada S, Krajewski S, Miyashita T, Krajewska M and Reed JC (1996) $\gamma$-irradiation induces upregulation of Bax protein and apoptosis in radiosensitive cells in vivo. Oncogene 12: 187-192

Kress S, König J, Schweizer J, Löhrke H, Bauer-Hofmann R and Schwarz M (1992) p53 mutations are absent from carcinogen-induced mouse liver tumors but occu in cell lines established from these tumors. Mol. Carcinogenesis 6: 148-158

Labarca C and Paigen K (1980) A simple, rapid, and sensitive DNA assay procedure. Anal. Biochem. 102: 344-352

Lämmli UK (1970) Cleavage of structure proteins during assembly of the head of bacteriophage T4. Nature 227: 680-685

Levine AJ (1997) p53, the cellular gatekeeper for growth and division. Cell 88: $323-$ 331

Lindenboim L, Diamond R, Rothenburg E and Stein R (1995) Apoptosis induced by serum deprivation of $\mathrm{PC} 12$ cells is not preceded by growth arrest and can occurat each phase of the cell cycle. Cancer Res. 55: 1242-1247

Lowe SW, SchmittEM, Smith SW, Osborne BA and Jacks T (1993) p53 is required for radiation-induced apoptosis in mouse thymocytes. Nature 362: 847-849

MacCallum DE, Hupp TR, Midgley CA, Stuart D, Campbell SJ, Harper A, Walsh FS, Wright EG, Balmain A, Lane DP and Hall PA (1996) The p53 response to ionising radiation in adult and developing murine tissues. Oncogene 13: 2575-2587
Merchant AK, Loney TL and Maybaum J (1996) Expression of wild-type p53 stimulates an increase in both Bax and Bcl- $x_{\mathrm{L}}$ protein content in HT29 cells. Oncogene 13: 2631-2637

Merritt AJ, Potten CS, Kemp CJ, Hickman JA, Balmain A, Lane DP and Hall PA (1994) The role of p53 in spontaneous and radiation-induced apoptosis in the gastrointestinal tract of normal and p53-deficient mice. Cancer Res. 54: 614617

Midgley CA, Owens B, Briscoe CV, Thomas DB, Lane D and Hall PA (1995) Coupling between gamma irradiation, p53 induction and the apoptotic response depends on cell type in vivo. J. Cell Sci. 108: 1843-1848

Miyashita T, Krajewski S, Wang HG, Lin HK, Liebermann DA, Hoffman B and Reed JC (1994) Tumor suppressor p53 is a regulator of bcl-2 and bax gene expression in vitro and in vivo. Oncogene 9: 1799-1805

Miyashita T and Reed JC (1995) Tumor suppressor p53 is a direct transcriptional activator of the human bax gene. Cell 80: 293-299

Mueller M, Strand S, Hug H, Heinemann EM, Walczak H, Hofmann WJ, Stremmel W, Krammer PH and Galle PR (1997) Drug induced apoptosis in hepatoma cells is mediated by the CD95(APO-1/FAS) receptor/ligand system and involves activation of wild-type p53. J. Clin. Invest. 99: 403-413

Nagata S (1997) Apoptosis by death factor. Cell 88: 355-365

Ni R, Tomita Y, Matsuda K, Ichihara A, Ishimura K, Ogasawara J, Nagata S (1994) Fas-mediated apoptosis in primary cultured mouse hepatocytes. Exp. Cell Res. 215: $332-337$

Oltvai Z, Milliman C and Korsmeyer S (1993) Bcl-2 heterodimerizes with a conserved homolog, Bax, that accelerates programmed cell death. Cell 74: 609-619

Oltvai Z and Korsmeyer S (1994) Checkpoints of dueling dimers foil death wishes. Cell 79: $189-192$

Owen-Schaub LB, Zhang W, CusackJC, Angelo LS, Santee SM, Fujiwara T, Roth JA Deisseroth AB, Zhang W-W, Kruzel E and Radinsky R (1995) Wild-type human p53 and a temperature-sensitive mutant induce Fas/APO-1 expression. Mol. Cell. Biol. 15: 3032-3040

Rowan S, Ludwig RL, Haupt Y, Bates S, Lu X, Oren M and Vousden KH (1996) Specific loss of apoptotic but not cell cycle-arrest function in a human tumor derived p53 mutant. EMBO J. 15: 827-838

Sabbatini P, Lin J, Levine AJ and White E (1995) Essential role for p53-mediated transcription in E1A-induced apoptosis. Genes Dev. 9: 2184-2192

Schwarz M, Buchmann A, Stinchcombe S, Luebeck G, Moolgavkar S and Bock KW (1995) Role of receptors in human and rodent hepatocarcinogenesis. Mut. Res. 333: $69-79$

Sedlak T, Oltvai Z, Yang E, Wang K, Boise L, Thompson C and Korsmeyer S (1995) Multiple $\mathrm{Bcl}-2$ family members demonstrate selective dimerizations with Bax. Proc. Natl. Acad. Sci. USA 92: $7834-7838$

Smith PK, Krohn RI, Hermanson GT, Mallia AK, Gartner FH, Provenzano MD, Fujimoto EK, Goeke NM, Olson B and Klenk DC (1985) Measurement of protein using bicinchonicic acid. Anal. Biochem. 150: 76-85

Strasser A, Harris AW, Jacks T and Cory S (1994) DNA damage can induce apoptosis in proliferating lymphoid cells via p53-independent mechanisms inhibitable by Bcl-2. Cell 79: 329-339

Strobel T, Swanson EL, Korsmeyer S and Cannistra SA (1996) BAX enhances paclitaxel-induced apoptosis through a p53-independent pathway. Proc. Natl Acad. Sci. USA 93: 14094-14099

Symonds H, Krali L, Remington L, Saenz-Robies M, Lowe S, Jacks T and Van Dyce T (1994) P53-dependent apoptosis suppresses tumor growth and progression in vivo. Cell 78: 703-711

Tanaka M, Ito H, Adachi S, Akimoto H, Nishikawa T, Kasajima T, Marumo F and Hiroe M (1994) Hypoxia induces apoptosis with enhanced expression of Fas antigen messenger RNA in cultured neonatal rat cardiomyocytes. Circ. Res. 75: 426433

Unger C, Kress S, Buchmann A and Schwarz M (1994) $\gamma$-irradiation-induced micronuclei from mouse hepatoma cells accumulate high levels of the tumor suppressor protein p53. Cancer Res. 54: 3651-3655

Yin C, Knudson CM, Korsmeyer SJ and Van Dyke T (1997) Bax suppresses tumorigenesis and stimulates apoptosis in vivo. Nature 385: 637-640

Zhan QM, Alamo I, Boise LH, Cherney B, Tosato G, O'Connor P and Fornace AJ Jr (1996) The apoptosis-associated gamma-ray response of $B C L-X_{L}$ depends on normal p53 function. Oncogene 13: 2287-2293

Zhan Q, Fan S, Bae J, Guillot C, Liebermann DA, O'Connor P and Fornace AJ J (1994) Induction of bax by genotoxic stress in human cells correlates with normal p53 status and apoptosis. Oncogene 9: 3743-3751 